\title{
Detection of Yersinia pseudotuberculosis in Apollo Butterfly (Parnassius apollo, Lepidoptera: Papilionidae) Individuals from a Small, Isolated, Mountain Population
}

\author{
Kinga Łukasiewicz, Marek Sanak and \\ Grzegorz Węgrzyn \\ Additional information is available at the end of the chapter
}

http://dx.doi.org/10.5772/66462

\begin{abstract}
Yersinia pseudotuberculosis is a bacterium pathogenic to humans and other mammals; however, its insecticidal activity has also been documented in laboratory studies. A small population of Apollo butterfly (Parnassius apollo), reconstituted from less than 30 individuals in 1990s, occurs in Pieniny National Park (Poland). In this report, we demonstrate that a DNA fragment specific to Y. pseudotuberculosis could be detected in $40 \%$ of biological samples isolated from insects belonging to the Apollo butterfly population. Although Y. pseudotuberculosis DNA occurred in both normal and malformed insects, the difference between the fractions of infected individuals was statistically significant ( $p=0.044$ in the Fisher's exact test). No such DNA could be detected in analogous samples from other butterflies (Pieris napi, Pieris rapae, and Zerynthia polyxena) occurring in separate habitats (either a meadow near the city of Cracow, Poland, or in a mountain region of Greece). It is suggested that infection with Y. pseudotuberculosis might weaken the general condition of the P. apollo population from Pieniny and contribute to the appearance of developmental abnormalities of the butterflies. Thus, it appears that Y. pseudotuberculosis infections of insects may be of biological significance in natural environment.
\end{abstract}

Keywords: Apollo butterfly, deformed wings, reduced wings, Yersinia pseudotuberculosis, isolated butterfly population 


\section{Introduction}

Yersinia pseudotuberculosis is a bacterium pathogenic to humans and other mammals. However, it also reveals insecticidal activity due to the production of specific toxins [1,2]. Infections with this bacterium cause a serious, often deadly, disease of various insects, including species belonging to Lepidoptera [3, 4]. Nevertheless, reports indicating occurrence of Y. pseudotuberculosis in insects and its pathogenicity to these hosts are based on laboratory, rather than environmental, studies.

Parnassius apollo (Lepidoptera: Papilionidae), known as Apollo butterfly, is a rare, seriously endangered species. It is often considered as near threatened [5], despite the fact that its population in Europe was relatively large for some 100 years ago [6]. While reason(s) for $P$. apollo extinction are debatable, and only partially explained [7], various programs for saving and reconstitution of this butterfly have been established. In Pieniny National Park (Poland), the population of Apollo butterfly declined to less than 30 individuals at the beginning of the last decade of twentieth century [8]. Nevertheless, a specific program allowed to enlarge this population significantly [9]. On the other hand, surprisingly frequent appearance of malformed butterflies has been noted [10]. Such insects occurred in the natural environment of Pieniny National Park, but this phenomenon was more pronounced in the reared population, kept in seminatural conditions in order to increase the number of $P$. apollo individuals (most probably, malformed insect died and/or were eaten in the natural environment). The most striking malformed phenotypes include deformation and reduction of wings [10]. Examples of malformed individuals, in comparison with the normal one, are depicted in Figure 1.
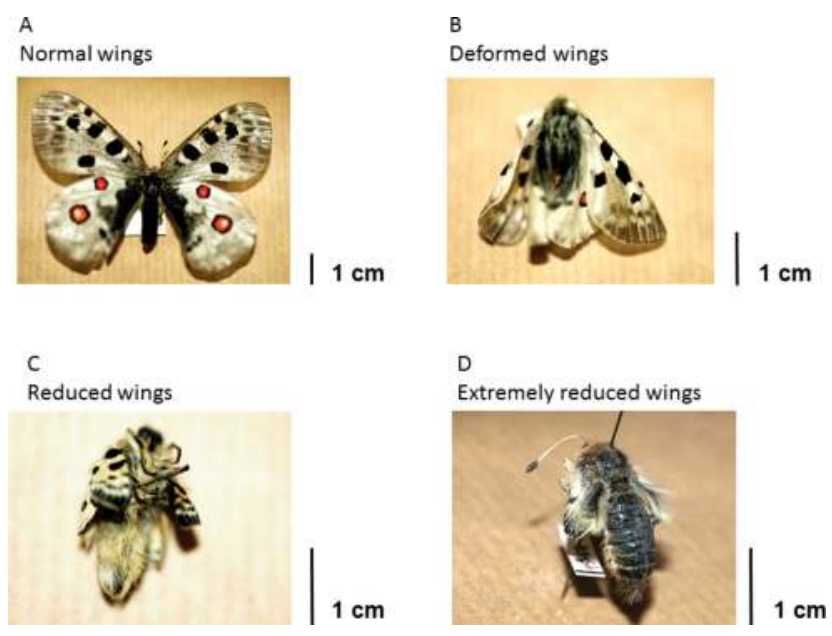

Figure 1. Examples of P. apollo individuals with different patterns of wings: normal (A, wings characteristic for healthy butterflies), deformed (B, wings of the size similar to normal, but with changed shape and arrangement), reduced (C, wings smaller than normal, sometimes with different morphology), and extremely reduced (D, very small wings, resembling buds rather than mature organs, sometimes almost invisible). Photographs made by the authors. 
Until recently, the cause of the malformations in P. apollo from Pieniny was unknown. However, when genetic materials from normal and malformed insects were compared, some significant differences could be identified. In butterflies with deformed or reduced wings, mutations in the wingless gene, coding for a protein involved in wing development, were found to be common [11]. Deficiency in laccases, enzymes which are involved in detoxification of some compounds found in normal diet of caterpillars, was significantly more frequent in malformed than in healthy butterflies [12]. Moreover, many individuals with deformed or reduced wings did not contain Wolbachia, a prokaryotic symbiont that can modulate some important physiological processes in insects [13]. These results indicate that there are genetic, biochemical, and microbiological reasons for malformations of wings in the isolated population of P. apollo. On the other hand, statistical analyses indicated that none of the mentioned reasons can be considered a sole cause of the developmental changes [11-13]. Therefore, further studies on this phenomenon appear to be warranted. In this report, we present evidence that a considerable fraction of the population of Apollo butterfly from Pieniny is infected with Yersinia pseudotuberculosis.

\section{Materials and methods}

\subsection{Insects}

Insects used in this work were either withdrawn from a meadow near the city of Cracow, Poland (individuals of P. napi, P. rapae), taken from a mountain region in Greece and obtained from a private collection of butterflies (individuals of Z. polyxena) or obtained from the collection of dried insects of Pieniny National Park (individuals of P. apollo). The permission for the use of this material has been obtained from the Director of Pieniny National Park (permission no. PB-5232-24/07, topic ID: p0748). For DNA isolation, a material from 3 specimens of $P$. napi, 4 of $P$. rapae, and 2 of $Z$. polyxena, and 15 of $P$. apollo was used. Among P. apollo individuals, 12 had normal wings and 3 had malformed wings.

\subsection{DNA isolation and amplification}

A material extracted from legs of investigated insects was used for DNA studies. This material was subjected to wash using deionized water before the procedure to avoid environmental contamination. The procedure was conducted by employing the Sherlock AX Purification Kit (A\&A Biotechnology), according to the manufacturer's instruction. Following PCR-mediated amplification of specific DNA fragments (using primers listed in Table 1), they were separated by agarose gel electrophoresis and analyzed as described previously [14].

\subsection{DNA cloning and sequencing}

Selected products of DNA amplification were cloned into a plasmid vector by using the TOPO TA Cloning Kit Dual Promoter (with pCR II-TOPO vector) with One Shot TOPO10F' Chemically Competent Escherichia coli (Invitrogen). DNA sequencing was conducted com- 
mercially in the Laboratory of DNA Sequencing and Oligonucleotide Synthesis, Institute of Biochemistry and Biophysics of the Polish Academy of Sciences (Warsaw, Poland).

\begin{tabular}{lll}
\hline Gene & Primers (forward and reverse) & References \\
\hline$d p p$ & 5' AGA GAA CGT GGC GAG ACA CTG & {$[24]$} \\
& 5' GAG GAA AGT TGC GTA GGA ACG & \\
$h h$ & 5' AAG GAA AAA CTG AAT ACG CTG GC & {$[24]$} \\
& 5' CGA GAC GCC CCA ACT TTC C & \\
$p t c$ & 5' CTC CGA AGA AGG TCT GCC GCA AG & {$[24]$} \\
5' AAT TCG TGC TCG TCG TAT TTT C & \\
inv & 5' TAA GGG TAC TAT CGC GGC GGA & {$[15]$} \\
\hline
\end{tabular}

Table 1. Specific primers used in PCR.

\subsection{Statistical analysis}

Since only a low number of samples could be analyzed (due to restrictions caused by regulations of $P$. apollo protection and protective rules of the collection of Pieniny National Park), the statistical analysis was performed by using the Fisher's exact test. Statistical significance was assumed when $p<0.05$.

\section{Results}

In the course of our studies on the reasons of deformation and reduction of wings in the population of P. apollo from Pieniny National Park, we tested various genes involved in the development of differentiation of various insect organs. Since Apollo butterfly genome has not been sequenced yet, in order to amplify some genes, primers were designed on the basis of DNA sequences from other insects. Although this strategy was often successful [11, 12], specific DNA fragments were unambiguously identified (e.g., those amplified with primers for $d p p$, $h h$, and ptc genes, listed in Table 1; this was also a positive control for the quality of DNA samples) in some cases and no amplification products of desired genes could be obtained. Instead, in a few cases, PCR-derived DNA fragments of unexpected lengths appeared and were particularly abundant. An example was $\sim 160$-bp PCR product, amplified with the use of primers (5'-TCG GAA AAA TTG TGG ATC GAG G and 5'-AAA TCC GAA GCC GAT GTT GTC) initially devoted for amplification of the wg gene fragment (with expected length of $220 \mathrm{bp}$, assuming a sequence homology of the $w g$ gene from P. apollo to that from other insects). This 160-bp DNA fragment was cloned in a plasmid vector and sequenced (the actual length of the insert was $158 \mathrm{bp}$ ). The BLASTx-mediated search indicated a homology to two proteins of Y.pseudotuberculosis, an RND family efflux transporter and hemolysin secretion protein D. 
These results suggested a possibility of the presence of this bacterium in a biological material withdrawn from bodies of investigated insects. Therefore, we aimed to test this hypothesis.

Using primers specifically designed to identify Y. pseudotuberculosis (reported previously [15]), it was possible to detect the presence of this bacterium in samples from normal and malformed P. apollo individuals. Among 15 samples tested, the Y. pseudotuberculosis-specific PCR product was detected in 6 (Table 2). Three of them were from normal individuals, and three of them were from insects with deformed or reduced wings. Statistical analysis indicated that the malformed butterflies were significantly more often infected than normal individuals $(p=0.044$ in the Fisher's exact test). In control experiments, no Y. pseudotuberculosis-specific DNA could be detected in samples from P. napi, P. rapae, and Z. polyxena (Table 2). These control samples came from insects withdrawn from habitats located outside of Pieniny National Park, that is, either a meadow near the city of Cracow (Poland) or a mountain region in Greece.

\begin{tabular}{llll}
\hline Species and characteristics & \multicolumn{2}{l}{ Number of individuals used for DNA isolation } \\
\cline { 2 - 4 } & All tested & $\begin{array}{l}\text { With } \text { inv specific } \\
\text { PCR product }\end{array}$ & $\begin{array}{l}\text { Without } \text { inv specific } \\
\text { PCR product }\end{array}$ \\
\hline P. napi (normal) & 3 & 0 & 3 \\
P. rapae (normal) & 4 & 0 & 4 \\
Z. polyxena (normal) & 2 & 0 & 2 \\
P. apollo (normal) & 12 & 3 & 9 \\
P. apollo (with malformed wings) & 3 & 3 & 0
\end{tabular}

${ }^{a}$ The $p$ value, in the Fisher's exact test, for normal individuals vs. malformed insects was 0.044 .

Table 2. Results of PCR-mediated DNA amplification with the use of indicated templates and primers specific to the inv gene of Y. pseudotuberculosis.

\section{Discussion}

Pathogenicity of Y.pseudotuberculosis to insects was demonstrated previously under laboratory conditions $[3,4]$. Its detection in samples from P. apollo individuals coming from Pieniny National Park indicates that this bacterium can infect butterflies in natural habitats and may suggest that the investigated Apollo butterfly population is endangered by insecticidal activity. Although the extinction of this population due to Y. pseudotuberculosis infection is rather unlikely, the presence of this pathogen may significantly weaken the insects. One might suggest that $Y$. pseudotuberculosis infections could contribute to developmental changes observed in these insects. Although statistically significant difference was found between the frequency of infected normal and malformed Apollo butterflies, detection of Y. pseudotuberculosis in samples from healthy individuals demonstrated that the infection occurs in the entire population. Perhaps, butterflies weakened by other factors, such as deficiency of laccase or the 
absence of Wolbachia, might be more susceptible and more sensitive to Y. pseudotuberculosis infection.

The presence of Y. pseudotuberculosis in butterflies from Pieniny National Park, and its absence in samples from other butterflies withdrawn from other habitats (either in Poland or in Greece), might seem surprising. However, this bacterium has also been described as a pathogen of sheep around the world [16-19]. There is a broad area of a sheep pasture ecosystem in Pieniny, where sheep grazing is particularly extensive [20]. Importantly, it occurs even at upper mountain parts. Therefore, sheep can be considered as a source of $Y$. pseudotuberculosis in this region. Bacteria may be excreted with feces of sheep, causing contamination of local plants [21, 22], and then, they can be spread through various animals, becoming potential infectious agents for insects in Pieniny National Park. One might suppose that infections of $P$. apollo by $Y$. pseudotuberculosis could contribute to developmental abnormalities of butterflies, due to weakening of the insects and causing physiological disturbance, especially in combination with genetic, biochemical, and symbiosis problems which the population in Pieniny suffers from (and which were described previously [11-13]). Interestingly, insecticidal activity of cell extracts from Yersinia enterocolitica, a species closely related to Y. pseudotuberculosis and producing the same kinds of toxins, was demonstrated to be present only when bacteria were cultured at low temperature $\left(10^{\circ} \mathrm{C}\right)$, in contrast to higher temperature $\left(30^{\circ} \mathrm{C}\right)$ [23]. Because the population of $P$. apollo in Pieniny exists in the mountain region, where temperatures are commonly around $10^{\circ} \mathrm{C}$ from late spring to early fall, a deleterious effect of $Y$. pseudotuberculosis infection on this population seems likely.

The question appears what might be effects of infections of Apollo butterflies with Y. pseudotuberculosis? In fact, in our work, focused on the biological material from a collection, we could only detect the presence of this bacterium in samples of insect bodies. To determine how severe such infections could be, laboratory studies, with experimental administration of bacteria to insects' bodies would be necessary. Then, symptoms of the infection might be observed and investigated, with assessment of their severity. Moreover, it would be particularly interesting to test whether Y. pseudotuberculosis infection affects the development of Apollo butterfly. Again, experimental studies with the use of P. apollo, including larvae and imago forms, would be necessary. The problem is that Apollo butterfly is a rare species (particularly subspecies frankenbergeri, occurring in Pieniny), protected by law. Thus, no individuals can be withdrawn from their natural habitat to conduct biological experiments. The only possibility would be to use insects from a culture; however, to our knowledge, no such culture is currently available.

\section{Acknowledgements}

This work was supported by Ministry of Science and Higher Education (Poland) (project Grant No. N N304 339633 to Kinga Łukasiewicz) and the University of Gdańsk (task Grant No. 530L140-D242-16-1A). The authors declare no conflict of interest. 


\section{Author details}

Kinga Łukasiewicz ${ }^{1,2}$, Marek Sanak ${ }^{1}$ and Grzegorz Węgrzyn ${ }^{2 *}$

*Address all correspondence to: grzegorz.wegrzyn@biol.ug.edu.pl

1 Division of Molecular Biology and Clinical Genetics, Department of Medicine, Jagiellonian University Medical College, Cracow, Poland

2 Department of Molecular Biology, University of Gdańsk, Gdańsk, Poland

\section{References}

[1] Erickson DL, Waterfield NR, Vadyvaloo V, Long D, Fischer ER, Ffrench-Constant R, Hinnebusch BJ. Acute oral toxicity of Yersinia pseudotuberculosis to fleas: implications for the evolution of vector-borne transmission of plague. Cell Microbiol. 2007;9:26582666.

[2] Waterfield N, Hares M, Hinchliffe S, Wren B, Ffrench-Constant R. The insect toxin complex of Yersinia. Adv Exp Med Biol. 2007;603:247-257.

[3] Pinheiro VB, Ellar DJ. Expression and insecticidal activity of Yersinia pseudotuberculosis and Photorhabdus luminescens toxin complex proteins. Cell Microbiol. 2007;9:2372-2380.

[4] Champion OL, Cooper IA, James SL, Ford D, Karlyshev A, Wren BW, Duffield M, Oyston PC, Titball RW. Galleria mellonella as an alternative infection model for Yersinia pseudotuberculosis. Microbiology. 2009;155:1516-1522.

[5] van Swaay C, Wynhoff I, Verovnik R, Wiemers M, López Munguira M, Maes D, Sasic M, Verstrael T, Warren M, Settele J Parnassius apollo. The IUCN Red List of Threatened Species. 2010. Version 2015.2. <www.iucnredlist.org>

[6] Nakonieczny M, Kędziorski A, Michalczyk K. Apollo butterfly (Parnassius apollo L.) in Europe - its history, decline and perspectives of conservation. Funct Ecosyst Commun. 2007;1:56-79.

[7] Łozowski B, Kędziorski A, Nakonieczny M, Łaszczyca P. Parnassius apollo last-instar larvae development prediction by analysis of weather condition as a tool in the species' conservation. C R Biol. 2014;337:325-331.

[8] Witkowski Z, Adamski P. Decline and rehabilitation of the Apollo butterfly Parnassius apollo (Linnaeus, 1758) in the Pieniny National Park (Polish Carpathians). In: Settele J, Margules CR, Poschlod P, Henle K, editors. Species Survival in Fragmented Landscapes. Dordrecht, The Netherlands: Kluwer Academic Publishers; 1996. pp. 7-14. 
[9] Witkowski Z, Adamski P, Kosior A, Płonka P. Extinction and reintroduction of Parnassius apollo in the Pieniny National Park (Polish Carpathians). Biologia. 1997;52: 199-208.

[10] Adamski P, Witkowski Z. Wing deformation in an isolated Carpathian population of Parnassius apollo (Papilionidae: Parnassinae). Nota Lepid. 1999;22:67-73.

[11] Łukasiewicz K, Sanak M, Węgrzyn G. Lesions in the wingless gene of the Apollo butterfly (Parnassius apollo, Lepidoptera: Papilionidae) individuals with deformed or reduced wings, coming from the isolated population in Pieniny (Poland). Gene. 2016;576:820-822.

[12] Łukasiewicz K, Węgrzyn G. Changes is genes coding for laccases 1 and 2 may contribute to deformation and reduction of wings in apollo butterfly (Parnassius apollo, Lepidoptera: Papilionidae) from the isolated population in Pieniny National Park (Poland). Acta Biochim Pol. 2016;63:177-180.

[13] Łukasiewicz K, Sanak M, Węgrzyn G. A lack of Wolbachia-specific DNA in samples from apollo butterfly (Parnassius apollo, Lepidoptera: Papilionidae) individuals with deformed or reduced wings. J Appl Genet. 2016;57:271-274.

[14] Sambrook J, Russell DW. Molecular Cloning: A Laboratory Manual, 3rd ed. Cold Spring Harbor, NY: Cold Spring Harbor Laboratory Press; 2001.

[15] Nakajima H, Inoue M, Mori T, Itoh K, Arakawa E, Watanabe H. Detection and identification of Yersinia pseudotuberculosis and pathogenic Yersinia enterocolitica by an improved polymerase chain reaction method. J Clin Microbiol. 1992;30:2484-2486.

[16] Philbey AW, Glastonbury JR, Links IJ, Matthews LM. Yersinia species isolated from sheep with enterocolitis. Aust Vet J. 1991;68:108-110.

[17] Slee KJ, Skilbeck NW. Epidemiology of Yersinia pseudotuberculosis and Y. enterocolitica infections in sheep in Australia. J Clin Microbiol. 1992;30:712-715.

[18] Severini M, Ranucci D, Miraglia D, Cenci Goga BT. Pseudotuberculosis in sheep as a concern of veterinary public health. Vet Res Commun. 2003;27(Suppl 1):315-318.

[19] Magistrali CF, Cucco L, Pezzotti G, Farneti S, Cambiotti V, Catania S, Prati P, Fabbi M, Lollai S, Mangili P, Sebastiani C, Bano L, Dionisi AM, Luzzi I. Characterisation of Yersinia pseudotuberculosis isolated from animals with yersiniosis during 1996-2013 indicates the presence of pathogenic and Far Eastern strains in Italy. Vet Microbiol. 2015;180:161-166.

[20] Andrzejewska L. Analysis of a sheep pasture ecosystem in the Pieniny Mountains (the Carpathians). V. Herbivores and their effect on plant production. Ekol Pol. 1974;22: 527-534. 
[21] Czerwiński Z, Jakubczyk H, Tatur A, Traczyk T. Analysis of a sheep pasture ecosystem in the Pieniny Mountains (the Carpathians). VII. The effect of penning-up sheep on soil, microflora and vegetation. Ekol Pol. 1974;22:547-558.

[22] Jakubczyk H. Analysis of a sheep pasture ecosystem in the Pieniny Mountains (the Carpathians). VIII. Development of microflora in dung and in soil of a spring sheepfold. Ekol Pol. 1974;22:559-568.

[23] Bresolin G, Morgan JA, Ilgen D, Scherer S, Fuchs TM. Low temperature-induced insecticidal activity of Yersinia enterocolitica. Mol Microbiol. 2006;59:503-512.

[24] Kapan DD, Flanagan NS, Tobler A, Papa R, Reed RD, Gonzalez JA, Restrepo MR, Martinez L, Maldonado K, Ritschoff C, Heckel DG, McMillan WO. Localization of Müllerian mimicry genes on a dense linkage map of Heliconius erato. Genetics. 2006;173:735-757. 
